Meta

Journal des traducteurs

Translators' Journal

\title{
On the Threshold of the Next Generation of Bible Translations: Issues and Trends
}

\section{Jacobus A. Naudé}

Volume 50, numéro 4, décembre 2005

Pour une traductologie proactive - Actes

For a Proactive Translatology - Proceedings

Por una traductología proactiva - Actas

URI : https://id.erudit.org/iderudit/019851ar

DOI : https://doi.org/10.7202/019851ar

Aller au sommaire du numéro

Éditeur(s)

Les Presses de l'Université de Montréal

ISSN

0026-0452 (imprimé)

1492-1421 (numérique)

Découvrir la revue

Citer cet article

Naudé, J. A. (2005). On the Threshold of the Next Generation of Bible

Translations: Issues and Trends. Meta, 50(4). https://doi.org/10.7202/019851ar
Résumé de l'article

Le but de cette communication est d'examiner les problèmes et les tendances ayant trait à la nouvelle génération de traductions de la Bible. La communication commence par décrire la situation actuelle de la traduction biblique, avant d'examiner de plus près les éditions de la Bible publiées récemment : la Contemporary English Bible (1995), Das Neue Testament (1999), The Schocken Bible, Tome 1 (1995), et la Nieuwe Bijbel Vertaling (2004). Dans la seconde moitié du XXe siècle, le sens et la lisibilité des textes dominent dans la production de traductions reflétant davantage l'équivalence dynamique que la formelle. La Bible in Today's English (1976), la Groot Nieuws Bijbel (1983), et la Nuwe Afrikaanse Vertaling (1983) en sont des exemples. Au tournant du siècle dernier on assiste à la création de traductions ayant comme fonction première la communication (il s'agissait de la réécriture, dans une langue vernaculaire, de textes bibliques, généralement par un seul traducteur ou éditeur), par exemple The Message en anglais (2000) et en afrikaans (2002). Toutefois ces traductions dépendent de la capacité du lecteur de comprendre le texte écrit. Une nouvelle tendance dans la traduction de la Bible devra tenir compte des besoins de ceux qui entendent et de ceux qui lisent. On peut s'attendre, aussi, à ce que la nouvelle traduction biblique s'éloigne du langage typique des traductions de la seconde moitié du XXe siècle; cela peut se faire, par exemple, en resensibilisant les lecteurs à la distance qui les sépare de la culture source.
Ce document est protégé par la loi sur le droit d'auteur. L'utilisation des services d’Érudit (y compris la reproduction) est assujettie à sa politique d'utilisation que vous pouvez consulter en ligne.

https://apropos.erudit.org/fr/usagers/politique-dutilisation/ 


\title{
On the Threshold of the Next Generation of Bible Translations: Issues and Trends
}

\author{
JACOBUS A. NAUDÉ \\ University of the Free State, Bloemfontein, South Africa \\ naudej.hum@mail.uovs.ac.za
}

\begin{abstract}
RÉSUMÉ
Le but de cette communication est d'examiner les problèmes et les tendances ayant trait à la nouvelle génération de traductions de la Bible. La communication commence par décrire la situation actuelle de la traduction biblique, avant d'examiner de plus près les éditions de la Bible publiées récemment: la Contemporary English Bible (1995), Das Neue Testament (1999), The Schocken Bible, Tome 1 (1995), et la Nieuwe Bijbel Vertaling (2004). Dans la seconde moitié du XXe siècle, le sens et la lisibilité des textes dominent dans la production de traductions reflétant davantage l'équivalence dynamique que la formelle. La Bible in Today's English (1976), la Groot Nieuws Bijbel (1983), et la Nuwe Afrikaanse Vertaling (1983) en sont des exemples. Au tournant du siècle dernier on assiste à la création de traductions ayant comme fonction première la communication (il s'agissait de la réécriture, dans une langue vernaculaire, de textes bibliques, généralement par un seul traducteur ou éditeur), par exemple The Message en anglais (2000) et en afrikaans (2002). Toutefois ces traductions dépendent de la capacité du lecteur de comprendre le texte écrit. Une nouvelle tendance dans la traduction de la Bible devra tenir compte des besoins de ceux qui entendent et de ceux qui lisent. On peut s'attendre, aussi, à ce que la nouvelle traduction biblique s'éloigne du langage typique des traductions de la seconde moitié du XXe siècle; cela peut se faire, par exemple, en resensibilisant les lecteurs à la distance qui les sépare de la culture source.
\end{abstract}

\begin{abstract}
The aim of this paper is to describe the issues and trends facing the next generation of Bible translations. The paper starts with a description of the state of art of Bible translation before exposing features of the recently published Contemporary English Bible (1995), Das Neue Testament (1999), The Schocken Bible, Volume 1 (1995) and the Nieuwe Bijbel Vertaling (New Dutch Version) (2004). In the second part of the twentieth century a primary concern for meaning and readability has influenced the trend to produce translations which are more reflective of dynamic equivalence than formal equivalence. Examples are the Bible in Today's English (1976), the Groot Nieuws Bijbel (Bible in Today's Dutch) (1983) and the Nuwe Afrikaanse Vertaling (New Afrikaans Version) (1983). At the turn of the century translations with communication as their primary function were created (normally a rewriting of an existing translation in a modern vernacular by a single translator/editor), for example The Message in English (2000) and Afrikaans (2002). However, all these translations depend heavily on the reader's ability to understand a written text. A new trend in Bible translation will take into consideration the requirements of the hearer, as well as those of the reader (the translation has to be read out aloud, heard and listened to). A shift away from the typical language usage of the Bible translations in the second half of the $20^{\text {th }}$ century is the offing i.e. by instilling a new awareness in the minds of the readers to the sociocultural distance between them and the source culture.
\end{abstract}

MOTS-CLÉS/KEYWORDS

Bible translation, Great ages of Bible translation, generations of Bible translation, cultural knowledge, socio-cultural distance

\section{Introduction}

The aim of this paper is to describe the issues and trends facing the next generation of Bible translations. The paper starts with a description of the development path of the previous generations 
of Bible translations before exposing features of the recently published Contemporary English Bible (1995), Das Neue Testament (1999), The Schocken Bible, Volume 1 (1995) and the New Dutch Version (2004). The description is done within the Frames of Reference model as proposed by Timothy Wilt (2003). Key concerns are: the socio-cultural as well as organizational setting of a translation, the communicative goals of the various participants in the translation process, community values, and cognitive factors influencing the arrangement and interpretation of text signs. It is shown how the communication situation of Bible translation throughout the world has changed dramatically since the second half of the $20^{\text {th }}$ century. Orlinsky and Bratcher (1991:179) view the 1960s as the advent of a new epoch in Bible translation, the so-called Fourth Great Age of Bible translation.

\section{The Four Great Ages of Bible Translation}

The First Great Age (about 200 BCE to the fourth century CE) has a Jewish setting (Alexandria and Western Asia) and the target languages involved were Greek (Septuagint) and Aramaic (Targums).

The Second Great Age (fourth century CE to about 1500 or the Middle/Dark Ages) was Catholic in origin with its main centers Palestine and the burgeoning Christian communities in the Roman Empire. The target language was Latin (Jerome's Vulgate). A salient feature of this age is the Christianizing of the Hebrew source text; which means reading in new meaning and nuances into Hebrew and Greek-Septuagint words and phrases.

The Third Great Age (about 1500 - 1960) essentially stands in the sign of Protestantism. The target languages include English, German, French, Dutch, Spanish, etc. The main centers of activity were located in those regions where the (essentially Protestant) trade communities ousted the old (essentially Catholic) feudalist establishments. In the process of translation there was a noticeable adherence to the word for word philosophy of translation and to the pristine vocabulary and style. The products of translation were characterized by a desire for the greatest possible transmission of the forms and structure of the source text, both at the macro- and micro-level. The pragmatic functions of the source text received scant attention. Famous translations of this era are the King James Version (KJV) or Authorized Version (AV), the American Standard Version (ASV), the Dutch Authorized Version, etc. The Old Afrikaans Version (1933/1953) and the Dutch Bible Society Version (NBG, 1951) also demonstrate the characteristics of this era.

It is unanimously agreed that the Revised Standard Version (RSV) (1952-1975) was transitional towards the Fourth Great Age/Epoch/Phase in Bible translation (Bruce 1978; Daniell 2003). This period introduces a significant change in the overall philosophy of Bible translation. It shows the unprecedented attempt on the part of the Jewish, Catholic, and Protestant communities in the United States and Great Britain to cooperate inter-confessionally. Secondly the RSV was the end of the mechanical, word for word reproduction of the Hebrew and Greek text, a procedure that haunted Bible translation from the very outset. Instead, the focus is to make the plain meaning intended in the source texts accessible to their readers. Amongst those who played a pivotal role in the development of the theory and practice of Bible translation at this stage are Eugene A. Nida and his colleagues of the American Bible Society and the United Bible Societies. Nida \& Taber (1969) view translation as reproducing in the receptor language the closest natural equivalent of the source text first in terms of meaning and secondly in terms of style. A translation is dynamic equivalent to the source text if the message of the source text has been transported into the receptor language in such a way that the response of the receptor is essentially that of the original receptors. In what follows the developmental path of Bible translation in this age is described.

\section{The Fourth Great Age of Bible Translation}

\subsection{The First Generation: Corporate Bible Translations}

The latter half of the twentieth century witnessed the appearance of a large number and variety of new English versions of the Bible amounting to about twenty-seven English renderings of the entire 
Bible (Metzger 2001:117). The important translations were invariably new and not revisions. This represents a distinctive departure from the KJV-RSV tradition of the previous period. One exception was the New American Standard Version (NASB), a revision of the ASV of 1901, sponsored by a private foundation. A second definitive break with the KJV tradition is the nature of the translation committees. The new translations emanated from corporate committees consisting of senior scholars from many denominations. However, interconfessional co-operation as a natural product of the common body of scholarship on which the translation work has been based was still tardy. The Jerusalem Bible (JB) was a thoroughly Catholic project, the New Jewish Version (NJV) thoroughly Jewish, and the New English Bible (NEB) (Barr 1974:381-405), the New International Version (NIV), and Today's English Version (TEV) thoroughly Protestant. Only the New American Bible (NAB) resulted from active collaboration between Catholic and Protestant scholars. $\mathrm{JB}$ and NEB are more British in style and vocabulary, and the others more American.

The Today's English Version (TEV) (known as the Good News Bible) (1976) is a prototype of what may comfortably be called the first generation of Bible translations of the Fourth Age. It was commissioned by the American Bible Society to be a completely modern translation on a level of language usage which could be readily understood by any reader of English, regardless of his/her education (Lewis 1981: 261-291; Kubo \& Specht 1983: 171-197). There was a demand for a translation especially designed for those who speak English as an acquired language. It was published in what is termed common language (the overlap between the literary and the colloquial) in order to reach out beyond the Church to a largely secular constituency. This was the first English translation to make consistent use of advances in general linguistics and in translation theory. Translators were chosen not as representatives of any denominational position, but on the basis of concurrence with the principles of the project and professional experience. Their translation theory was based on the scholarship of Eugene Nida and the product exhibits a dynamic equivalence translation. Other examples are the Groot Nieuws Bijbel (Bible in Today's Dutch) (1983) and the Nuwe Afrikaanse Vertaling (New Afrikaans version) (1983).

\subsection{The Second Generation: Simplified Versions and Paraphrases}

Various kinds of revisions and variations of the main versions were produced (cf. Coleman 1989). Attempts were made to produce paraphrase translations, translations concerned primarily with translation meaning, translations reflecting contemporary Biblical scholarship, and translations using inclusive language to reduce the sexist language of the Biblical text. They are translations with communication as its primary function, normally a rewrite of an existing translation in a modern vernacular sometimes by a single translator/editor (Metzger 2001:175-185). Some of these seek to serve the needs of particular population groups: children, the youth, women, Christian converts and dialectal speakers. For these large groups of consumers the Bible should not be found disturbing. They belong to the second generation of Bible translations of the fourth era. For example the Living Bible, Paraphrased (LB) $(1967,1971)$ by Kenneth Taylor, used the American Standard Version of 1901 as source. The Reader's Digest Bible (1982) by Bruce M. Metzger is an abridgement of the Revised Standard Version (1952). The vocabulary and language structures of these eminently readable versions reflect the language usage of the average person. The result is that they are simplified versions at a reading level of third or fourth grade and is intended as a stepping stone to the more formal/traditional versions. For example The New International Reader's Version (1996/1998) is a simplified version intended as a stepping stone to the New International Version (Barker 1999). The translators were most sensitive to gender-inclusive wording. For example the term "brothers" is rendered as "brothers and sisters". In the Message (1993, 1997, 2000), Eugene Peterson refrained from choosing simple English words, but rather words which forcefully convey the meaning to the reader, for example addendum, consummate, embryonic. He often dissociated passages from their first-century Mediterranean context so that Jesus, for example, sounds like a twentieth-century American. In Matthew 5:47 Jesus says, If you simply say hello to those who greet you, do you expect a medal? Any run-of-the-mill sinner does that. One salient feature of these versions appears to be the use they make of interpretive selection. Every instance where the Hebrew or Greek texts are ambiguous, one view is adopted and rendered clearly. True 
paraphrase involves not only the modernized English equivalent of what is in the text itself, but introduces something which is not there in order to elucidate the meaning of what is there.

The Contemporary English Version (CEV) (1995) by Barclay M. Newman as editor was an exception. Made directly from the original texts, it is not a paraphrase or modernization of any existing traditional version. Since more people hear the Bible being read out aloud than read it themselves, Newman and his colleagues set themselves the task to listen carefully and decide on the way in which each word in their version would be understood when read out aloud. This translation sets the stage towards the third generation of Bible translations of the Fourth Age.

\section{Towards the next generation of Bible translations of the Fourth Age}

\subsection{To be read out aloud: Contemporary English Version (CEV)}

The CEV was translated as an effort to produce a text to be faithful to the meaning of the original and easily readable and comprehensible by readers of all ages. The CEV clearly positions itself within the mainstream of modern linguistics with its assertion of the primacy of the spoken over the written word (Newman 1996). The welcome" page of the Contemporary English Version (1995) described it as 'user-friendly' and 'mission-driven' translation that can be read aloud without stumbling, heard without misunderstanding, and listened to with enjoyment and appreciation, because the style is lucid and lyrical. These points are important and are missed in translations of the 20th century.

This translation was originally designed for children (at a fourth grade reading level). However, it was so appealing to adults that the translators (American Bible Society) decided to direct it to this wider readership. It was made directly from the original languages of the Scriptures and is not an adaptation of any existing translation. The translators carefully studied every word of the source text in order to find the best way to translate the verse and render it more easily read and understood (Porter 1999:18-46). Poetic sections were expected not only to sound good but also to look good. Poetic lines were carefully measured to assist oral reading and to avoid awkwardly divided phrases and words that run over to the next line clumsily.

Early dawn outlines the hills

like stitches on clothing

or sketches on clay.

But its light is too much

for those who are evil,

and their power is broken. (Job 38:14-15).

However, many Biblical distinctions and concepts are deleted from the CEV for all practical purposes. For example, the CEV translators held the view that the biblical way of saying God spoke through the prophets was too difficult for children, and so the very concept was eliminated. (e.g. Hebrews 1:1 God's prophets spoke his message to our ancestors" instead of "God spoke to our ancestors through the prophets.) Key theological words, including grace, justification, righteousness, sanctification, redemption, atonement, repentance, and covenant, are avoided in the $\mathrm{CEV}$. The CEV is very careful to steer young readers away from the old "sexist" interpretations found in all Bibles prior to their generation. In Genesis 2:18, Eve is called not a helper but a partner of Adam; in 1 Peter 3:1, Colossians 3:18 and Ephesians 5:22 women are advised to put their husbands first rather than told plainly to submit to them (rendered obey elsewhere in the CEV). The CEV also avoids the word Jews wherever it is used in reference to opponents of Jesus. So instead of Jews they give the people or the religious leaders.

The CEV fails to withdraw from the language of the New York Times, which characterized the language usage of the second generation of Bibles of this era. As illustrated above, this custom suppressed the linguistic and cultural differences of the source text, assimilating it to dominant values in the target-language culture, making it familiar and therefore ostensibly original. It creates 
the impression that Bible personalities share the same popular culture as the readers. A new trend in Bible translation is to instill a new sensitivity among readers to the socio-cultural gap between them and the original contexts of the Bible. The socio-cultural distance is achieved in one way in Das Neue Testament (1999).

\subsection{Bridge the cultural gap (Otherness understand): Das Neue Testament (1999)}

The cultural distance between the source-culture author and his or her forms of expression (verbal and nonverbal), on the one hand, and any target-culture audience, on the other, is ever present, even though, in some specific cases, it may not be relevant to the particular communicative act in question or to such a minimal extent as to warrant no consideration. There are two situations that result in an intense experience of a gap between cultures (Nord 2002:98). The first case is when the lack of culture-specific background knowledge makes it impossible to establish coherence between what is said and what is known. The second case is when nonverbal and verbal behaviour do not match due to the fact that the nonverbal behaviour cannot be interpreted correctly. These two factors impede coherence, or even render it impossible, in the reception of Biblical texts i.e. texts from which the target audience is separated by a wide cultural gap.

Nord (1997:24-25) defines the culture barrier between two groups as consisting of rich points where differences in behavior may cause communication conflicts. This means that, when confronted with a particular translation task, a translator has to be very sensitive towards the rich points between the groups or subgroups on either side of the language-and-culture barrier, even though it may well be decided to leave the barrier intact and just try to assist people on either side to peep across and understand the otherness of what is happening over there (Nord 2002:104-106). This means that there may be situations in translation where it is essential to bridge the cultural gap and others where the translator is supposed to leave the gap open and insist on the cultural distance between source and target cultures (cf postcolonial translation studies and the resistive approaches to translation). The actual choice is pragmatically defined by the purpose of the intercultural communication.

In Das Neue Testament Berger and Nord (1999) present an alien culture in a way that allows readers from a culture remote in time and space to understand and appreciate its otherness. Nord (2002: 110) illustrates the way in which the lack of cultural knowledge diminishes the appellative function of a passage, as in the following description of the New Jerusalem (Revelation 21:18-21). The source text readers knew the colors of the precious stones mentioned, whereas this is not the case with the target text readers. This is the reason why the colors of the stones are added. The Today's English Version treats the source text like a technical description.

(i) Today's English Version

The wall was made of jasper, and the city itself was made of pure gold, as clear as glass. The foundation-stones of the city wall were adorned with all kinds of precious stones. The first foundation-stone was jasper, the second sapphire, the third agate, the fourth emerald, the fifth onyx, the sixth carnelian, the seventh yellow quartz, the eighth beryl, the ninth topaz, the tenth chalcedony, the eleventh turquoise, the twelfth amethyst. The twelve gates were twelve pearls; each gate was made from a single pearl. The street of the city was of pure gold, transparent as glass. (ii) Das Neue Testament, 1999 (translated into English)

The city wall is made of jasper, and the city itself of gold that is as pure as glass. The foundations of the city wall are of great beauty, for they are built out of precious stones in many different colors. The first foundation-stone is green jasper, the second blue sapphire, the third red agate, the fourth light green emerald, the fifth reddish brown onyx, the sixth yellowish red carnelian, the seventh yellow-gold quartz, the eighth beryl as green as the sea, the ninth shining yellow topaz, the tenth chalcedony, shimmering green-golden, the eleventh deep red turquoise, the twelfth purple amethyst. The twelve gates are twelve pearls; each gate is made from a single pearl. The main street of the city is of gold as pure as glass. 
However, although the socio-cultural distance is addressed, Das Neue Testament is directed towards the reader and not the listener. An example where the demands of the listener as well as the bridging of the socio-cultural distance (although in another way as in Das Neue Testament) are achieved is in the The Schocken Bible Volume 1.

\subsection{Facilitate reading and restore cultural knowledge: The Schocken Bible Volume 1}

In the Translator's Preface it is stated that the purpose of this work is to draw the reader into the world of the Hebrew Bible through the power of its language (Fox 1995: IX-XXVI). The reader will encounter a text which challenges him or her to rethink what these ancient books stand for and what they signify, and will hopefully be encouraged to become an active listener rather than a passive receiver. This translation is guided by the principle that the Hebrew Bible, like much of the literature of antiquity, was meant to be read out aloud, and that consequently it must be translated with careful attention to rhythm and sound. The translation therefore tries to mimic the particular rhetoric of the Hebrew whenever possible, preserving such devices as repetition, allusion, alliteration, and wordplay. It is intended to echo the Hebrew, and to lead the reader back to the sound structure and form of the original. Such an approach was first espoused by Martin Buber and Franz Rosenzweig in their monumental German translation of the Bible (1925-1962). The Five Books of Moses is in many respects an offshoot of the Buber-Rosenzweig translation.

Fox (1995:XV-XVIII) also propounds three innovations characteristic of his translation: Firstly, the general layout, that is, the idea of presenting each clause on a separate line, in order to create the impression of blank verse as opposed to prose. His practice of dividing the text into lines indicates a striking departure from the concept of the Hebrew Bible as a written book and restores the sense of it as spoken performance. Cola divisions do facilitate reading aloud and make it possible for the listener to sense the text's inner rhythm-and only at that point can the text begin to deliver its message with full force. Secondly, the restoration of personal names and place names to a form more closely resembling of the Hebrew original. Thirdly, there is a concentrated effort to reproduce the Leitwort/leading word technique. Metatexts include notes and commentary.

Personal names are important in the text of the Hebrew Bible because they were given to the characters, which cause or experience the events forming the plot. As opposed to English or Afrikaans where very few people even know the original meaning of a proper name in Hebrew the naming of a person is meaningful and is usually associated with a particular event. Up till now these names were adjusted so as to blend into the English or Afrikaans phonological and morphological structure. In this process many connotations were lost. Fox transferred such names into English where at all possible. Consequently, for example, the Hebrew Avraham instead of Abraham, Moshe is retained instead of Moses, Kayin instead of Cain, Rivka instead of Rebecca, Havva instead of Eve, and Bil'am instead of Balaam. However, the transcription fails to differentiate clearly between a he and het-sound, for example Hevel and Havva on the one hand and Hanokh and Noah on the other. The meaning of a name is often explained directly in the text itself. This is indicated by a slash in the text.

May God extend/yaft

Yefet,

let him dwell in the tents of Shem,

but may Canaan be servant to them! (Genesis 9:27) (Fox 1995:27)

Especially in oral culture, key words are repeated within a text to signify major themes and interests. Operating on the basis of sound, the repetition of a word or word root encourages the listener to relate diverse parts of a story, to one another and to follow a particular theme throughout. If the keywords are substituted while carefully observing the sound in the target text, the oral character is given prominence. The same applies to wordplay, allusion and small-scale repetition. Contrary to traditional translations where key words were omitted at random, Fox' strategy of substitution is a resounding success. In the story of the meeting between Jacob and Esau, the motif of face occurs at crucial points in the story. 
For he said to himself:

I will wipe (the anger from) his face

with the gift that goes ahead of my face;

afterward, when I see his face,

perhaps he will lift up my face!

The gift crossed over ahead of his face...(Gen 32: 21-22). Fox (1995:153-155)

Fox uses specification, as a device to transmit cultural activity, and accomplishes this by aid of hyphenation to produce single English words (or so-called phrasal words (Newmark 1988:147)) for single Hebrew terminology with double meanings. The Hebrew word ruach which means both wind and spirit is rendered by rushing-spirit (Gen 1:2), rushing-wind (Gen 8:1) and (breath of) the rush (of life) (Gen 7:22).

Das Neue Testament and The Schocken Bible can be classified as exotic. They have an exclusive readership. The New Dutch Translation (NBV) is an inter-confessional Bible translation brought out with the aim of providing a standard translation for all Dutch speakers. The next Bible translation in Afrikaans (contemplated for 2006) follows the same trends in its planning phase as that of the New Dutch Translation

\subsection{Middle-of-the-road position: Nieuwe Bijbel Vertaling (NBV) (2004)}

The basis for the NBV-approach is as follows. It is not just the message that needs to be communicated. There is a growing interest among Christians world-wide in the ways the biblical texts are structured, the beauty and impact of poetical language, the rhetorical features of texts, etc. (cf. Lorein 1994). Consequently, there is an ever increasing demand for translations which assume a middle-of-the road stance. The new approach acknowledges the fact of a great diversity within the Scriptures of style and genre with its characteristic forms, structures and themes. All of these have to be reflected one way or another in the translated text, taking full advantage of the contemporary linguistic and literary resources of both the source and the receptor language (Noorda 2002:8-16). The translation will not just copy source language forms and structures, because the translation aims at contemporary, natural Dutch. The pragmatics of the receptor language takes priority in the translation.

Given the growing interest in the Bible as an ancient literary and inspirational document, the view took shape that this single translation would be able to meet the needs of church community and society at large (prospective literary uses of the translation). This broad approach to the issue of target audience in translation constituted yet another factor that contributed to the diversity in style, language level and extent of restructuring of the translated text. The NBV may presuppose a somewhat broader spectrum of background knowledge of the Bible and the biblical world, which is addressed to assist the reader.

NBV is a translation that can be read out aloud in church (recitable) and lends itself to chanting purposes. It has helpful notes and other assistance to the reader. It reflects the literary forms and structures of the source texts, and retains as much as possible biblical imagery and metaphor, provided they are functional in contemporary Dutch and express the correct intended meaning. Notes are available in case of alternative translations of the source text, if linguistically and exegetically sound; translations of names understood or alluded to in the text, which would be disturbing if incorporated in the text itself; and, play on words and other text features with an important function, but incapable of meaningful and natural expression in translation. These notes, as well as text-criticism, form an integral part of the translation and appear in all the editions of the NBV-Bible, whether Netherlands Bible Society, Catholic Bible Society or licensed editions.

The intended liturgical use of the translation implies that marked style in the source text at the rhetorical, syntactic and lexical level is reflected somehow in the translation. Functional repetition of biblical "motiv"-words in rhetorical texts is therefore recognizable in translation with as little variation as possible. The translation refrains from spelling out contextual implications and places greater stress on the explications of the biblical text. Many people are conversant with the 
biblical text and its background and do not expect a high level of implicit information being clarified. Moreover, it is typical of language to imply information to a greater or lesser extent, because which forms the intended message can to a large extent be inferred from the textual context. With regard to the Pauline epistles, more justice is done to Paul's condensed style by leaving implicit information in certain Greek genitive constructions more "open" than was the case in more meaning-based approaches.

Although one of the aims of the project is to translate natural, contemporary Dutch, this does not mean that e.g. technical terms like 'praetorium', 'centurio', 'legio' and military jargon used by the author of Acts, have to be avoided.

The translation team counts among its members professional translators and linguists. About 60 external reviewers represent the diversity of church denominations, including the Jewish religious community form book teams. A "book team" consists of the two translators, two reviewers and a biblical scholar and language expert from the coordinating staff group. At least two writers and/or literary critics are hired to review each Bible books from a literary perspective. The coordinating staff group reviews the contribution made by all these external reviewers in accordance with the project principles and proposes changes in the translated text for ratification by the project board.

\section{Conclusion}

Within the second part of the twentieth century a primary concern for meaning and readability has profoundly influenced the trend in Bible translations. The first generation translations bear testimony of dynamic equivalence. The second generation represents translations with communication as its primary function, normally a rewriting of an existing translation in a modern vernacular. However, this practice suppressed the linguistic and cultural differences of the source text by assimilating it to dominant values in the target-language culture. The third generation accentuates the role of the listener, which means that the emphasis is placed on the spoken language.

Our society is fast approaching a post-literature age. More people hear the Bible being read than read it for themselves. New readers tend to "sound out" a written text. Experienced readers often read poetry and lyrical prose aloud to experience the beauty and impact of poetical language. Hearing reinforces comprehension and assists the process of memorization. Any text that expresses its message in a manner that is easy for the ear to follow can be clearly rendered into print, but the reverse is not always true.

New Bible translation projects will need to account at least for the following aspects (cf. also Kee 1993):

1. Meet the need to be read out aloud in church (recitable) and to adaptable for chanting purposes;

2. Meet the need to fulfill prospective literary uses of the translation;

3. Add notes to clarify socio-cultural aspects of the source text;

4. Performing of Bible translations by teams including professional translators.

These points are of paramount importance but are ignored in most of the translations of the $20^{\text {th }}$ century.

\section{REFERENCES}

BARKER, K.L. (1999): The Balance of the NIV, Grand Rapids, Baker.

BARR, J. (1974): “After Five years. A Retrospect on Two Major Translations of the Bible," Heythrop College 15, p. 381-405.

BERGER, K und C. NORD (1999): Das Neue Testament und Frühchristliche Schriften, Frankfurt, Insel Verlag. BRUCE, F.F. (1978): History of the Bible in English. From the Earliest Versions, Oxford, Oxford University Press. 
Coleman, R. (1989): New Light and Truth. The Making of the Revised English Bible, Oxford, Oxford University Press.

DANIELL, D. (2003): The Bible in English. Its history and influence, New Haven \& London, Yale University Press. Fox, E. (1995): The Schocken Bible, Volume 1, The Five Books of Moses, New York, Schocken Books.

(1976): Holy Bible. Today's English Version, New York, United Bible Societies.

KeE, H.W. (1993): American Bible Society Symposium Papers on the Bible in the Twenty-First Century, Philadelphia, Trinity Press.

Kubo, S and W.F. SPECHT (1983): So many versions? Twentieth-century English Versions of the Bible, Grand Rapids, Baker.

LEWIS, J.P. (1981): The English Bible from KJV to NIV. A History and Evaluation, Grand Rapids, Baker.

(1971): Living Bible, Paraphrased, Chicago, Tyndale Press.

LOREIN, G. W. (1994): Naar een nieuwe bijbelvertaling? Leiden, Groen en Zoon.

Metzger, B.M. (2001): The Bible in Translation. Ancient and English Versions, Grand Rapids, Baker.

(2004): Nieuwe Bijbel Vertaling, Querido, Jongbloed.

(1970): New American Bible (NAB), New York, American bible Society.

(1963): New American Standard Bible (NASB). New York, American Bible Society.

(1973): New International Version of the Bible (NIV). Grand Rapids, Zondervan.

Newman, B. M. (1996): Creating and Crafting the Contemporary English Version: A New Approach to Bible

Translation, New York, American Bible Society.

NiDA, E. A. \& C. R. TABER (1974): The Theory and Practice of Translation, Leiden, Brill.

NORD, C. (1997): Translating as a purposeful activity: functionalist approaches explained, Manchester, St

Jerome Publishers.

NorD, C. (2002): "Bridging the Cultural Gap. Bible Translation as a Case in Point", Acta Theologica 22-1, p. 98116.

NoORDA, S. (2002): "New and Familiar: The Dynamics of Bible Translation", in A. Brenner \& J. W. van Henten, Bible Translation on the Threshold of the Twenty-First Century. Authority, Reception, Culture and Religion,

Sheffield, Sheffield Academic Press, p. 8-16.

Orlinksy, H. M. and R. G. BRATChER (1991): A History of Bible Translation and the North American

Contribution, Atlanta, Scholars Press

Peterson, E. (2002): The Message, Colorado Springs, NAV Press.

PORTER, S. (1999): "The Contemporary English Version and the Ideology of Translation" in S. E. PORTER E. \& R. S Hess (eds.) Translating the Bible. Problems and Prospects, Shefield, Sheffield Academic Press, p. 18-46.

(1982): Reader's Digest Bible. Pleasantville: Reader's Digest Association.

(1989): Revised English Bible (REB). Oxford \& Cambridge. Oxford University Press.

(1952): Revised Standard Version. Toronto, New York \& Edinburgh, Collins.

(1995): The Contemporary English Version. (CEV) New York, United Bible Societies

(1901): The Holy Bible. Newly edited by the American Revision Committee A.D. 1901_(American Standard Version

(ASV)). New York; American Bible Society.

(1970): The New English Bible. (NEB) Oxford \&Cambridge. Oxford University Press.

WiLT, T. (2003): Bible Translation. Frames of Reference, Manchester, St Jerome.

(1917): The Holy Scriptures according to the Masoretic Text. A New Translation with the Aid of Previous

Versions and with Constant Consultation of Jewish Authorities (JPS). Philadelphia, Jewish Publication Society.

(1966): The Jerusalem Bible, London, Darton, Longman \& Todd. 